\title{
Analisis Teori Transparansi Pengelolaan Keuangan Daerah di Indonesia
}

\author{
Nurhayati \\ Program Studi Ilmu Pemerintahan Fakultas Ilmu Sosial dan Ilmu Politik \\ Universitas Kepulauan Riau, Batam Indonesia \\ nurhayati_ip@yahoo.com
}

\begin{abstract}
The purpose of transparency is to provide open financial information for the community in order to realize good governance. in order to realize the good governance in relation to the implementation of regional autonomy, it is necessary to reform the management of regional finance and state financial reform. The implementation of regional autonomy in its entirety brings logical consequences in theform of governance and development based on sound financial management.Transparency will ultimately create horizontal accountability between local governments and communities in order to create clean, effective, efficient, accountable and responsive local governance of community aspirations and interests. The facts show that in the management of local budget / finance as if still compiled with the concept of less mature / perfect, in a hurry and finally born prematurely or not well. Regulations that are born prematurely certainly contain various weaknesses and deficiencies and even lack of direction. Moreover, if born in the condition of high political temperature that is the war of interest among agencies who feel authorized to regulate it so that the level of transparency of financial management, especially at the regional level still contains a lot of uncertainty and indecision in providing guidance to the direction of local financial management policy. This has resulted in confusion among local governments in managing their finances.
\end{abstract}

Keywords: analysis, regional finance and transparency

\begin{abstract}
Abstrak
Tujuan transparansi adalah menyediakan informasi keuangan terbuka bagi masyarakat dalam rangka mewujudkan penyelenggaraan pemerintahan yang baik (Good Governance). dalam rangka mewujudkan good governance tersebut dalam kaitannya dengan pelaksanaan otonomi daerah, maka diperlukan reformasi pengelolaan keuangan daerah dan reformasi keuangan negara. Penerapan otonomi daerah seutuhnya membawa konsekuensi logis berupa penyelenggaraan pemerintahan dan pembangunan berdasarkan manajemen keuangan yang sehat. Pada dasarnya penerapan prinsip transparansi keuangan sangat membantu penyusunan anggaran pemerintah daerah (RAPBD) yang objektif dan berkualitas. Prinsip akuntabilitas dan transparansi keuangan diyakini dapat mendukung usaha mewujudkan pilar-pilar penyelenggaraan pemerintahan yang bersih dan berwibawa. Tingkat transparansi pengelolaan keuangan khususnya di tingkat daerah masih banyak mengandung ketidakjelasan dan ketidaktegasan dalam memberikan pedoman kepada arah kebijakan pengelolaan keuangan daerah. Hal ini mengakibatkan kebingungan pemerintah daerah dalam pengelolaan keuangannya.
\end{abstract}

Kata kunci: analisis, keuangan daerah dan transaparansi

\section{PENDAHULUAN}

Bangsa Indonesia sebagai bagian dari masyarakat dunia memiliki kewajiban untuk secara terus-menerus berpartisipasi dalam mewujudkan pemerintahan yang baik (good governance). World Bank dalam Mardiasmo (2004:18) mendefenisikan Good governance sebagai suatu penyelenggaraan manajemen pembangunan yang sejalan dengan prinsip 
demokrasi, penghindaran salah alokasi dana investasi, pencegahan korupsi baik secara politik dan administratif. Kepemerintahan yang baik setidaknya ditandai dengan tiga elemen yaitu transparansi, partisipasi dan akuntabilitas. Transparansi dibangun atas dasar kebebasan memperoleh informasi. Partisipasi maksudnya mengikutsertakan keterlibatan masyarakat dalam pembuatan keputusan baik secara langsung maupun tidak langsung melalui lembaga perwakilan yang dapat menyalurkan aspirasinya. Sedangkan akuntabilitas adalah pertanggungjawaban kepada publik atas setiap aktivitas yang dilakukan.

Penganggaran merupakan suatu proses yang cukup rumit pada organisasi sektor publik, termasuk di antaranya pemerintah daerah. Hal tersebut berbeda dengan penganggaran pada sektor swasta. Pada sektor swasta anggaran merupakan bagian dari rahasia perusahaan yang tertutup untuk publik, namun sebaliknya pada sektor publik anggaran justru harus diinformasikan kepada publik untuk dikritik dan didiskusikan untuk mendapat masukan. Anggaran sektor publik merupakan instrumen akuntabilitas atas pengelolaan dana publik dan pelaksanaan program-program yang dibiayai dari uang publik (Mardiasmo, 2005; 61).

Dalam rangka mewujudkan good governance diperlukan perubahan paradigma pemerintahan yang mendasar dari sistem lama yang serba sentralistis, dimana pemerintah pusat sangat kuat dalam menentukan kebijakan. Paradigma baru tersebut menuntut suatu sistem yang mampu mengurangi ketergantungan dan bahkan menghilangkan ketergantungan pemerintah daerah kepada pemerintah pusat, serta bisa memberdayakan daerah agar mampu berkompetisi baik secara regional, nasional maupun internasional. Menanggapi paradigma baru tersebut maka pemerintah memberikan otonomi kepada daerah seluas-luasnya yang bertujuan untuk memungkinkan daerah mengurus dan mengatur rumah tangganya sendiri agar berdaya guna dan berhasil guna dalam penyelenggaraan pemerintahan dan pembangunan serta dalam rangka pelayanan kepada masyarakat. Penyelenggaraan otonomi daerah dilaksanakan dengan memberikan otonomi seluas-luasnya dan secara proporsional kepada daerah yang diwujudkan dengan adanya pengaturan, pembagian dan pemanfaatan sumber daya nasional yang berkeadilan serta adanya perimbangan keuangan antara pusat dan daerah.

Berlakunya Undang Undang Nomor 22 Tahun 1999 tentang Pemerintah Daerah, daerah diberi kewenangan yang luas untuk menyelenggarakan pengelolaan keuangannya sendiri. Hal ini tentu saja menjadikan daerah provinsi, kabupaten, dan kota menjadi entitasentitas otonom yang harus melakukan pengelolaan dan pertanggungjawaban keuangannya sendiri. Peraturan Pemerintah Nomor 105 Tahun 2000 yang merupakan turunan dari UndangUndang Nomor 22 Tahun 1999 dalam pasal 35 mengamanatkan bahwa "penatausahaan dan 
pertanggungjawaban keuangan daerah berpedoman pada standar akuntansi keuangan pemerintah". Pada tahun 2004 terbit Undang-Undang Nomor 1 Tahun 2004 tentang Perbendaharaan negara kembali mengamanatkan penyusunan laporan pertanggungjawaban pemerintah pusat dan daerah sesuai dengan standar akuntansi pemerintah. Pasal 56 ayat 4 Undang-Undang Nomor 1 Tahun 2004 menyebutkan bahwa Kepala Satuan Kerja Perangkat Daerah selaku Pengguna Anggaran atau Pengguna Barang memberikan pernyataan bahwa pengelolaan APBD telah diselenggarakan berdasarkan system pengendalian intern yang memadai dan akuntansi keuangan telah diselenggarakan sesuai dengan standar akuntansi pemerintah.

Keinginan untuk mewujudkan good governance merupakan salah satu agenda pokok reformasi yang diharapkan dapat dilaksanakan secara konsisten oleh pemerintah daerah. Masyarakat menuntut adanya akuntabilitas yang baik disertai dengan transparansi dan keterbukaan pengelolaan anggaran supaya masyarakat dapat turut serta dalam mengontrol dan memperbaiki kinerja pemerintah daerah.

Kebijakan Pemerintah Pusat yang memberlakukan otonomi daerah merupakan langkah yang konkrit dalam mewujudkan desentralisasi pemerintahan yang sesungguhnya. Maksud dari Pemerintah Pusat memberikan hak otonomi kepada pemerintah daerah adalah untuk mempercepat terwujudnya kesejahteraan masyarakat melalui peningkatan pelayanan, pemberdayaan, dan peran serta masyarakat. Seiring adanya pemberlakuan otonomi daerah oleh pemerintah pusat, maka pemerintah daerah mempunyai tanggungjawab yang lebih besar untuk mendayagunakan potensi daerahnya masing-masing demi memajukan daerah tersebut (Safitri, 2009).

Di sisi lain tuntutan transparansi dalam sistem Pemerintah semakin meningkat pada era reformasi saat ini, tidak terkecuali transparansi dalam pengelolaan keuangan Pemerintah Daerah. Pemerintah Daerah diwajibkan menyusun laporan pertanggungjawaban yang menggunakan sistem akuntansi yang diatur oleh pemerintah pusat dalam bentuk Undangundang dan Peraturan Pemerintah yang bersifat mengikat seluruh Pemerintah Daerah. Dalam system Pemerintah Daerah terdapat 2 subsistem, yaitu Satuan Kerja Pengelola Keuangan Daerah (SKPKD) dan Satuan Kerja Perangkat Daerah (SKPD). Laporan Keuangan SKPD merupakan sumber untuk menyusun Laporan Keuangan SKPKD, oleh karena itu setiap SKPD harus menyusun Laporan Keuangan sebaik mungkin.

Sebagai upaya konkrit untuk mewujudkan transparansi dan akuntabilitas pengelolaan keuangan negara/daerah adalah penyampaian laporan pertanggungjawaban keuangan 
pemerintah yang memenuhi prinsip tepat waktu dan dapat diandalkan (reliable) serta disusun dengan mengikuti Standar Akuntansi Pemerintahan (SAP) yang telah diterima secara umum. Hal ini diatur dalam Peraturan Pemerintah Nomor 58 Tahun 2005 tentang Pengelolaan Keuangan Daerah dan Peraturan Menteri Dalam Negeri (Permendagri) Nomor 13 tahun 2006 tentang Pedoman Pengelolaan Keuangan Daerah.

Satuan Kerja Perangkat Daerah (SKPD) merupakan bagian dari pemerintah daerah yang melaksanakan fungsi pemerintahan dan pelayanan publik, baik secara langsung ataupun tidak. Untuk melaksanakan tugas pokok dan fungsinya tersebut, SKPD diberikan alokasi dana (anggaran). Oleh karena itu, kepala SKPD disebut juga Pengguna Anggaran (PA).

Selaku Pemegang Kekuasaan Pengelolaan Keuangan Daerah (PKPKD), Kepala Daerah (Gubernur, Bupati, Walikota) yang mendelegasikan sebagian kewenangannya kepada kepala SKPD, pada akhirnya akan meminta kepala SKPD membuat pertanggungjawaban atas kewenangan yang dilaksanakannya. Bentuk pertanggungjawaban tersebut bukanlah SPJ (surat pertanggungjawaban), tetapi berupa laporan keuangan. Penyebutan SKPD selaku entitas akuntansi (accounting entity) pada dasarnya untuk menunjukkan bahwa SKPD melaksanakan proses akuntansi untuk menyusun laporan keuangan yang akan disampaikan kepada Gubernur/Bupati/Walikota melalui Pejabat Pengelola Keuangan Daerah sebagai bentuk pertanggungjawaban pengelolaan keuangan daerah.

Pada dasarnya penerapan prinsip transparansi keuangan sangat membantu penyusunan anggaran pemerintah daerah (RAPBD) yang objektif dan berkualitas. Prinsip akuntabilitas dan transparansi keuangan diyakini dapat mendukung usaha mewujudkan pilar-pilar penyelenggaraan pemerintahan yang bersih dan berwibawa. Jika pemerintah daerah mampu menerapkan prinsip tersebut dalam setiap aktivitas penyusunan anggarannya, maka kinerja penyusunan anggaran yang berkualitas akan tercapai dengan semestinya.

Setiap daerah dengan semestinya sudah harus memperlihatkan prinsip transparansi keuangan secara kongkrit dalam penyusunan anggaran. Konsistensi penerapan akuntabilitas dan transparansi keuangan tersebut tidak hanya pada saat rencana anggaran disusun, tetapi juga saat implimentasi dan pengawasan anggaran di lapangan. Masing-masing SKPD selaku pemegang agency publik harus memperlihatkan itikad yang sunguh-sungguh dalam mengelola dana publik seraya memberikan informasi yang akurat dan benar kepada pihak pihak yang memerlukan. Dengan demikian SKPD yang berada dibawah pemerintah daerah sudah dapat dievaluasi tentang prestasi, kegagalan, kemampuan, dan loyalitasnya sebagai penilaian kinerja aparatur pemerintah yang bersih. 
Penerapan prinsip transparansi keuangan sudah dimulai sejak satuan kerja perangkat daerah pertama melaksanakan musyawarah perencanaan pembangunan. Kegiatan penyusunan anggaran yang jelas akan memotivasi para pelaksana bekerja lebih baik. Diperlukan kejelasan sasaran anggaran dan kejelasan tugas guna mencapai tujuan anggaran yang positif dan memberikan kepuasan bagi karyawan (Basri, 2003). Penyusunan dan penggunaan anggaran oleh masing-masing SKPD harus transparan. Tidak ada yang ditutup-tutupi. Hal ini karena RAPBD atau APBD merupakan anggaran milik publik. Publik yang berkepentingan memiliki hak untuk mengetahui bagaimana pemerintah telah menyusun dan melaksanakan program dengan menggunakan anggaran tersebut.

\section{PEMBAHASAN}

\section{Keuangan Daerah}

\section{Ruang Lingkup dan Pengelolaan Keuangan Daerah}

Dalam arti sempit, keuangan daerah yakni terbatas pada hal-hal yang berkaitan dengan APBD. Oleh sebab itu keuangan daerah identik dengan APBD. Menurut Mamesah dalam Halim (2004:18), Keuangan Daerah dapat diartikan sebagai semua hak dan kewajiban pemerintah yang dapat dinilai dengan uang. Demikian pula dengan segala sesuatu baik berupa uang maupun barang yang dapat dijadikan kekayaan daerah yang lebih tinggi serta pihak-pihak lain sesuai peraturan perundangan yang berlaku. Daerah adalah semua hak dan kewajiban daerah dalam rangka penyelenggaraan pemerintah daerah yang dapat dinilai dengan uang termasuk didalamnya segala bentuk kewajiban daerah tersebut perlu dikelola dalam suatu sistem pengelolaan keuangan daerah. Pengelolaan keuangan daerah merupakan subsistem dari sistem pengelolaan keuangan negara dan merupakan elemen pokok dalam penyelenggaraan pemerintah daerah. Lebih lanjut Halim (2004:20), ruang lingkup keuangan daerah terdiri dari keuangan daerah yang dikelola langsung dan kekayaan daerah yang dipisahkan. Yang termasuk dalam keuangan yang dikelola langsung adalah APBD dan barang-barang inventaris milik daerah. Sedangkan keuangan daerah yang dipisahkan meliputi Badan Usaha Milik Daerah (BUMD).

Dalam ketentuan umum pada PP Nomor 58 Tahun 2005, Pengelolaan Keuangan Daerah adalah keseluruhan kegiatan yang meliputi perencanaan, pelaksanaan, penatausahaan, pelaporan dan pertanggungjawaban, pengawasan 
daerah. Pengelolaan keuangan daerah dalam hal ini mengandung beberapa kepengurusan dimana kepengurusan umum atau yang sering disebut pengurusan administrasi dan kepengurusan khusus atau juga sering disebut pengurusan bendaharwan. Dalam pengelolaan anggaran atau keuangan daerah harus mengikuti prinsip-prinsip pokok anggaran sektor publik. Pada Permendagri Nomor 26 Tahun 2006 tentang Pedoman Penyusunan APBD Tahun Anggaran 2007 menyatakan bahwa "APBD harus disusun dengan memperhatikan prinsip-prinsip pokok anggaran sektor publik, sebagai berikut:
a. Partisipasi Masyarakat,
b. Transparansi dan Akuntabilitas Anggaran,
c. Disiplin Anggaran,
d. Keadilan Anggaran,
e. Efisiensi dan Efektivias Anggaran dan
f. Taat Asas.

Permendagri No. 13 tahun 2006 tentang Pedoman Pengelolaan Keuangan Daerah, sebagai pengganti Kepmendagri No. 29 tahun 2002 tentang Pedoman Pengurusan, Pertanggungjawaban dan Pengawasan Keuangan Daerah Serta Permendagri No. 13 ini merupakan pedoman umum bagi pemerintah daerah di dalam melaksanakan tata kelola keuangannya. Daerah masih mempunyai banyak pekerjaan rumah (PR-pent) yaitu harus menyusun aturan pelaksanaannya disesuaikan dengan kondisi dan karakteristik daerah, dalam bentuk Perda Pokok-Pokok Pengelolaan Keuangan Daerah dan berbagai Peraturan Kepala Daerah terkait dengan implementasinya.

Selain itu juga pengelolaan Keuangan Daerah adalah keseluruhan kegiatan yang meliputi perencanaan, pelaksanaan, penatausahaan, pelaporan, pertanggungjawaban, dan pengawasan keuangan daerah (PP 58/2005, pasal 1). Adapun Dasar Hukum Pengelolaan Keuangan Daerah:

1. UU 17/2003 tentang Keuangan Negara;

2. UU I/2004 tentang Perbendaharaan Negara;

3. UU 32/ 2004 tentang Pemerintah Daerah;

4. UU 33/2004 tentang Perimbangan Keuangan Pemerintah Pusat dan Pemerintah Daerah; 
5. PP 24/ 2005 tentang standar Akuntansi Pemerintah;

6. PP 58/2005 tentang Pengelolaan Keuangan Daerah;

7. PP No. 56/2005; Sistem Informasi Keuangan Daerah

8. PP No. 41/2007; Tentang organisasi perangkat daerah;

9. PP No. 38/2007; tentang Pembagian urusan Pemerintahan antara Pemerintah, Pemerintahan Daerah Provinsi, dan Pemerintahan Daerah Kabupaten/Kota

10. Permendagri No. 13/2006; tentang Pedoman Pengelolaan Keuangan Daerah;

11. Permendagri No. 59/2007; tantang Perubahan Atas Peraturan Menteri Dalam Negeri;

12. Permendagri No. 32/2008; pedoman penyusunan APBD tahun anggaran 2009;

13. Perda $11 / 2008$ tentang pokok-pokok pengeloaan Keuangan Daerah

\section{Anggaran Pendapatan dan Belanja Daerah (APBD)}

Anggaran Pendapatan dan Belanja Daerah selanjutnya disingkat APBD adalah suatu rencana keuangan tahunan pemerintah daerah yang disetujui oleh Dewan Perwakilan Rakyat Daerah (UU No. 17 Tahun 2003 pasal 1 butir 8 tentang Keuangan Negara). Semua penerimaan daerah dan pengeluaran daerah harus dicatat dan dikelola dalam APBD. Penerimaan dan pengeluaran daerah tersebut adalah dalam rangka pelaksanaan tugas-tugas desentralisasi. Sedangkan penerimaan dan pengeluaran yang berkaitan dengan pelaksanaan dekonsentrasi atau tugas pembantuan tidak dicatat dalam APBD.

APBD merupakan dasar pengelolaan keuangan daerah dalam satu tahun anggaran. APBD merupakan rencana pelaksanaan semua pendapatan daerah dan semua belanja daerah dalam rangka pelaksanaan desentralisasi dalam tahun anggaran tertentu. Pemungutan semua penerimaan daerah bertujuan untuk memenuhi target yang ditetapkan dalam APBD.

APBD disusun dengan pendekatan kinerja yaitu suatu sistem anggaran yang mengutamakan upaya pencapaian hasil kerja atau output dari perencanaan alokasi biaya atau input yang ditetapkan. Jumlah pendapatan yang dianggarkan dalam APBD merupakan perkiraan yang terukur secara rasional yang dapat tercapai untuk setiap sumber pendapatan. Pendapatan dapat direalisasikan melebihi jumlah anggaran yang telah ditetapkan. Berkaitan dengan belanja, jumlah belanja yang dianggarkan merupakan batas tertinggi untuk setiap jenis belanja. Jadi, realisasi belanja tidak boleh melebihi jumlah anggaran belanja yang telah ditetapkan. 
Penganggaran pengeluaran harus didukung dengan adanya kepastian tersedianya penerimaan dalam jumlah yang cukup. Setiap pejabat dilarang melakukan tindakan yang berakibat pengeluaran atas beban APBD apabila tidak tersedia atau tidak cukup tersedia anggaran untuk membiayai pengeluaran tersebut.

Anggaran Pendapatan dan Belanja Daerah (APBD) merupakan wujud pengelolaan keuangan daerah yang berdasarkan UU No. 17 Tahun 2003 merupakan rencana keuangan tahunan pemerintahan daerah yang disetujui oleh Dewan Perwakilan Rakyat Daerah (DPRD). Anggaran Pendapatan Dan Belanja Daerah merupakan kebijaksanaan keuangan tahunan pemerintah daerah yang disusun berdasarkan ketentuan Perundang-undangan yang berlaku, serta berbagai pertimbangan lainnya dengan maksud agar penyusunan, pemantauan, pengendalian dan evaluasi Anggaran Pendapatan dan Belanja Daerah mudah dilakukan. Pada sisi yang lain Anggaran Pendapatan dan Belanja Daerah dapat pula menjadi sarana bagi pihak tertentu untuk melihat atau mengetahui kemampuan daerah baik dari sisi pendapatan maupun sisi belanja

\section{Anggaran Daerah dan Pengelolaan Anggaran Pendapatan dan Belanja Daerah}

Bagi seorang akuntan anggaran dipandang sebagai sebuah cara untuk menulusuri keuangan pemerintah, karena dari uraian yang terdapat dalam anggaran terlihat secara jelas penggunaan dari uang negara sehingga dapat ditelusuri apa saja dan berapa banyak barang-barang yang dimiliki negara sebagai kekayaan negara, akibat adanya investasi pemerintah dalam anggaran negara. Sedangkan bagi ahli ekonomi anggaran adalah suatu alat untuk memperlancar atau menghambat terhadap produksi barang dan jasa. Menurut pandangan ahli ekonomi bahwa peranan anggaran sangat menentukan bagi berkembangnya suatu organisasi perusahaan, yang berarti dapat meningkatkan keuntungan bagi pemiliknya. Lain halnya menurut ahli Administrasi Negara, anggaran negara merupakan cara pengelolaan sumber-sumber pendapatan negara untuk membiayai program-program negara, berbeda dari sudut pandang ahli ekonomi yang berorientasi dengan keuntungan, para Administrasi Negara memandang bahwa dengan anggaran maka program-program pemerintah akan berjalan, demikian pula besar kecilnya anggaran juga mempengaruhi keberhasilan program-program pemerintah. 
Menurut Glenn A. Welsch dalam Adhim (2008) anggaran adalah suatu bentuk statement dari pada rencana dan kebijaksanaan manajemen yang dipakai dalam suatu periode tertentu sebagai petunjuk dalam periode itu. Sedangkan menurut $M$. Marsono anggaran dalam Dwi Eka (2011) adalah suatu rencana pekerjaan yang pada suatu pihak mengandung jumlah pengeluaran yang setinggi- tingginya yang mungkin diperlukan untuk membiayai kepentingan negara pada suatu masa depan dan pihak lain perkiraan pendapatan (penerimaan) yang mungkin akan dapat diterima dalam masa tersebut. Menurut Mardiasmo (2002: 62), anggaran publik berisi rencana kegiatan yang direpresentasikan dalam bentuk rencana perolehan pendapatan dan belanja dalam satuan moneter.

Berdasarkan Standar Akuntansi Pemerintahan (SAP, 2005: 104) yang dimaksud dengan anggaran adalah pedoman tindakan yang akan dilaksanakan pemerintah meliputi rencana pendapatan, belanja, transfer, dan pembiayaan yang diukur dalam satuan uang yang disusun menurut klasifikasi tertentu secara sistematis untuk satu periode.

Governmental Accounting Standarts Board (GASB) dalam Suhanda (2007;53) mendefinisikan anggaran adalah rencana operasi keuangan yang mencakup estimasi pengeluaran yang diusulkan, dan sumber pendapatan yang diharapkan untuk membiayainya dalam periode waktu tertentu.

Menurut Deddi Nordiawan (2007;39) Anggaran Pendapatan dan Belanja Daerah (APBD) merupakan rencana keuangan tahunan pemerintah daerah yang disetujui oleh DPRD dan ditetapkan dengan peraturan daerah.

Dalam Permendagri Nomor 13 tahun 2006 (pasal 15 dan 16) dijelaskan bahwa APBD mempunyai fungsi sebagai berikut:

a. Fungsi otorisasi, mengandung arti bahwa anggaran daerah menjadi dasar untuk melaksanakan pendapatan dan belanja pada tahun yang bersangkutan; -Fungsi perencanaan, mengandung arti bahwa anggaran daerah menjadi pedoman bagi manajemen dalam merencanakan kegiatan pada tahun yang bersangkutan ;

b. Fungsi pengawasan, mengandung arti bahwa anggaran daerah menjadi pedoman untuk menilai apakah kegiatan penyelenggaraan pemerintah daerah sesuai dengan ketentuan yang telah ditetapkan; 
c. Fungsi alokasi, mengandung arti bahwa anggaran daerah harus diarahkan untuk menciptakan lapangan kerja/mengurangi pengangguran dan pemborosan sumber daya, serta meningkatkan efisiensi dan efektifitas perekonomian;

d. Fungsi distribusi, mengandung arti bahwa kebijakan anggaran daerah harus memperhatikan rasa keadilan dan kepatutan;

e. Fungsi stabilisasi, mengandung arti bahwa anggaran pemerintah daerah menjadi alat untuk memelihara dan mengupayakan keseimbangan fundamental perekonomian daerah.

\section{Proses Penyusunan APBD}

Proses penyusunan anggaran diawali dengan penetapan tujuan, target dan kebijakan. Kesamaan persepsi antar berbagai pihak tentang apa yang akan dicapai dan keterkaitan tujuan dengan berbagai program yang akan dilakukan, sangat krusial bagi kesuksesan anggaran. Di tahap ini, proses panjang dari penentuan tujuan kepelakasanaan anggaran seringkali melewati tahap yang melelahkan, sehingga perhatian terhadap tahap penilaian dan evaluasi sering diabaikan. Kondisi inilah yang nempaknya secara praktis sering terjadi (Bastian, 2006 : 188)

Menurut Undang-undang nomor 17/2003, skema alur proses dan jadwal penyusunan APBD adalah sebagai berikut:

\section{Gambar 2.1 Alur Proses dan Jadwal Penyusunan APBD}

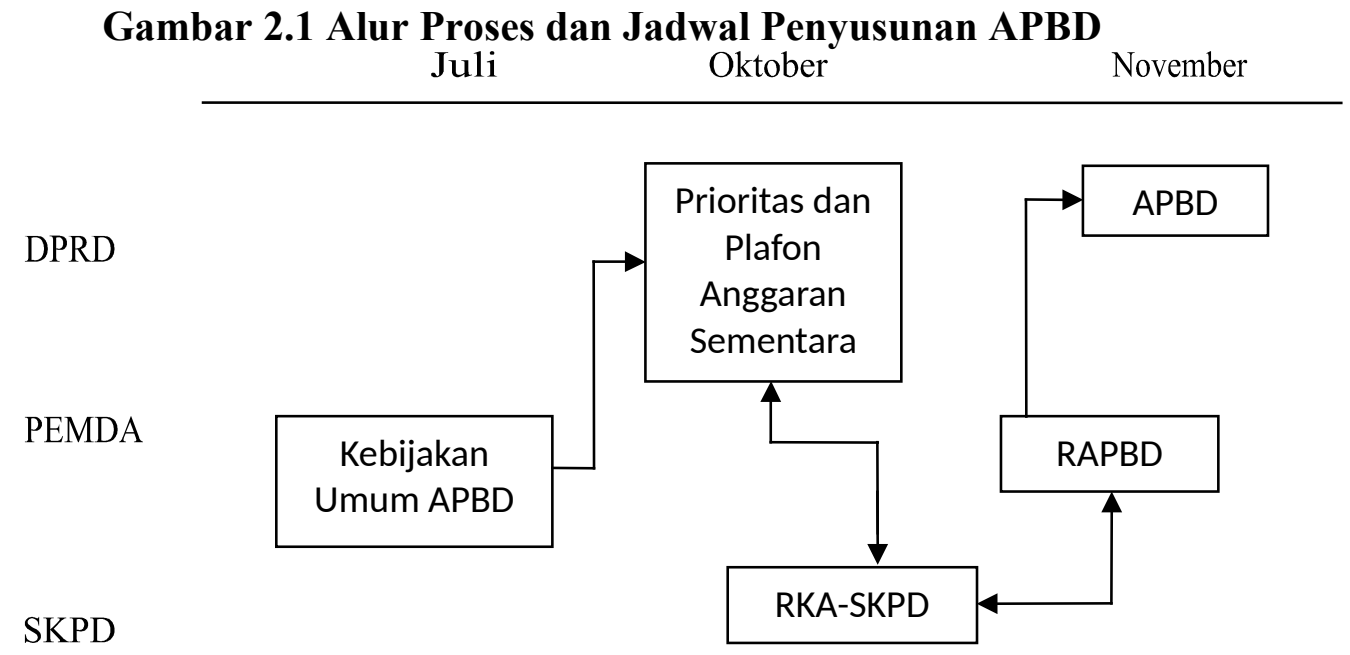

Sumber: Mohammad Admin, 2008. 
Dari gambar diatas dapat dilihat proses penyusunan APBD dimulai dengan pemerintahan daerah menyampaikan Kebijakan Umum APBD tahun anggaran berikutnta sejalan dengan Rencana Pemerintah Daerah sebagai landasan penyusunan RAPBD kepada DPRD membahas kebijakan umum RAPBD tahun anggaran berikutnya. Berdasarkan Kebijakan Umum APBD yang telah disepakati dengan DPRD, Pemerintah Daerah bersama DPRD membahas prioritas dan plafon anggaran sementara untuk dijadikan acuan bagi setiap Satuan Kerja Perangkat Daerah.

\section{Akuntansi Keuangan Pada Satuan Kerja Perangkat Daerah (SKPD)}

Dalam struktur Pemerintah Daerah, Satuan Kerja Perangkat Daerah (SKPD) merupakan entitas akuntansi yang mempunyai kewajiban melakukan pencatatan atas transaksi-tansaksi yang terjadi di lingkungan satuan kerja tersebut. Menurut Peraturan Menteri Dalam Negeri Nomor 13 tahun 2006 tentang Pedoman Pengelolaan Keuangan Daerah dalam kontribusi keuangan daerah, terdapat dua jenis Satuan Kerja yaitu:

1. Satuan Kerja Perangkat Daerah yang selanjutnya disingkat SKPD adalah perangkat daerah pada pemerintah daerah selaku pengguna anggaran/pengguna barang.

2. Satuan Kerja Pengelola Keuangan Daerah yang selanjutnya disingkat SKPKD adalah perangkat daerah pada pemerintah daerah selaku pengguna anggaran/pengguna barang, yang juga melaksanakan pengelolaan keuangan daerah.

Peraturan Menteri Dalam Negeri (Permendagri) Nomor 13 tahun 2006 (pasal 241 sampai dengan pasal 258) mengatur prosedur akuntansi penerimaan kas, pengeluaran kas, dan aset pada SKPD yang meliputi serangkaian proses mulai dari pencatatan, pengikhtisaran, sampai dengan pelaporan keuangan yang berkaitan dengan penerimaan kas, pengeluaran kas, dan atas perolehan, pemeliharaan, rehabilitasi, perubahan klasifikasi dan penyusutan terhadap aset tetap yang dikuasai/digunakan SKPD dalam rangka pertanggungjawaban pelaksanaan APBD yang dapat dilakukan secara manual atau dengan menggunakan aplikasi komputer.

Sedangkan Peraturan Menteri Dalam Negeri (Permendagri) Nomor 13 tahun 2006 (pasal 259 sampai dengan pasal 264) mengatur prosedur akuntansi selain kas pada SKPD yang meliputi serangkaian proses mulai dari pencatatan, pengikhtisaran, sampai dengan pelaporan keuangan yang berkaitan dengan semua 
transaksi atau kejadian selain kas yang dapat dilakukan secara manual atau dengan menggunakan aplikasi komputer.

Kegiatan akuntansi pada Satuan Kerja Perangkat Daerah (SKPD) meliputi pencatatan atas pendapatan, belanja, aset, dan selain kas. Proses tersebut dilakukan oleh Pejabat Penatausahaan Keuangan (PPK) SKPD berdasarkan dokumen-dokumen sumber yang diserahkan oleh bendahara.

Menurut Suhanda (2007,51), pihak-pihak yang terkait dalam kegiatan akuntansi SKPD adalah sebagai berikut:

1. Pejabat Pengguna Anggaran/Kuasa Pengguna Anggaran Adalah pejabat yang diberi kuasa untuk melaksanakan sabagian kewenangan pengguna anggaran dalam melaksanakan tugas dan fungsi SKPD. Kepala SKPD selaku kuasa pengguna anggaran bertanggungjawab terhadap anggaran yang dikelolanya. Dalam hal penatausahaan keuangan kepala SKPD menunjuk pejabat yang akan melaksanakan fungsi tersebut. Dalam Permendagri Nomor 13 tahun 2006 (pasal 10) tugas Pejabat Pengguna Anggaran mencakup :

a. Menyusun RKA-SKPD;

b. Menyusun DPA-SKPD;

c. Melakukan tindakan yang mengakibatkan pengeluaran atas beban anggaran belanja;

d. Melaksanakan anggaran SKPD yang dipimpinnya;

e. Melakukan pengujian atas tagihan dan memerintahkan pembayaran;

f. Melaksanakan pemungutan penerimaan bukan pajak;

g. Mengadakan ikatan/perjanjian kerjasama dengan pihak lain dalam batas anggaran yang telah ditetapkan;

h. Menandatangani SPM;

i. Mengelola utang dan piutang yang menjadi tanggungjawab SKPD yang dipimpinnya;

j. Mengelola barang milik daerah/kekayaan daerah yang menjadi tanggungjawab SKPD yang dipimpinnya;

k. Menyusun dan menyampaikan laporan keuangan SKPD yang dipimpinnya;

1. Mengawasi pelaksanaan anggaran SKPD yang dipimpinnya; 
m. Melaksanakan tugas-tugas pengguna anggaran/pengguna barang lainnya berdasarkan kuasa yang dilimpahkan oleh kepala daerah;

n. Bertanggungjawab atas pelaksanaan tugasnya kepada kepala daerah melalui sekretaris daerah.

2. Pejabat Pelaksana Teknis Kegiatan SKPD Adalah pejabat pada unit kerja SKPD yang melaksanakan satu atau beberapa kegiatan dari suatu program sesuai dengan bidang tugasnya. Dalam Permendagri Nomor 13 tahun 2006 (pasal 12 ayat 5) PPTK mempunyai tugas yang mencakup:

a. Mengendalikan pelaksanaan kegiatan;

b. Melaporkan perkembangan pelaksanaan kegiatan;

c. Menyiapkan dokumen anggaran atas beban pengeluaran pelaksanaan kegiatan.

Dokumen anggaran ini mencakup dokumen administrasi kegiatan maupun dokumen administrasi yang terkait dengan persyaratan pembayaran yang ditetapkan sesuai dengan ketentuan perundang-undangan.

3. Pejabat Penatausahaan Keuangan SKPD (PPK-SKPD) Adalah pejabat yang melaksanakan fungsi tata usaha keuangan pada SKPD. Dalam Permendagri Nomor 13 tahun 2006 (pasal 13 ayat 2), PPK-SKPD mempunyai tugas yang meliputi:

a. Meneliti kelengkapan SPP-LS pengadaan barang dan jasa yang disampaikan oleh bendahara pengeluaran dan diketahui/ disetujui oleh PPTK;

b. Meneliti kelengkapan SPP-UP, SPP-GU, SPP-TU dan SPP-LS gaji dan tunjangan PNS serta penghasilan lain yang ditetapkan sesuai dengan ketentuan perundang-undangan yang diajukan oleh bendahara pengeluaran;

c. Melakukan verifikasi SPP;

d. Menyiapkan SPM;

e. Melakukan verifikasi harian atas penerimaan;

f. Melaksanakan akuntansi SKPD

g. Menyiapkan laporan keuangan SKPD

4. Bendahara Penerimaan dan Bendahara Pengeluaran Adalah pejabat fungsional yang bertanggungjawab atas pelaksanaan tugasnya kepada PPKD selaku BUD, dalam pelaksanaan tugasnya dapat dibantu oleh bendahara penerimaan pembantu dan/atau bendahara pengeluaran pembantu. Bendahara SKPD 
memiliki tugas untuk menyiapkan dokumen-dokumen atas transaksi yang terkait dengan proses pelaksanaan akuntansi SKPD.

\section{Transparansi}

World Bank menyatakan bahwa transparansi adalah adanya keterbukaan yang dibangun diatas dasar kebebasan memperoleh informasi. Informasi yang berkaitan dengan kepentingan publik secara langsung dapat diperoleh oleh mereka yang membutuhkan tepat waktu (Ibid dalam Gerry Katon: 2013)

Transparansi adalah memberikan informasi keuangan yang terbuka dan jujur kepada masyarakat berdasarkan pertimbangan bahwa masyarakat memiliki hak untuk mengetahui secara terbuka dan menyeluruh atas pertanggungjawaban pemerintah dalam pengelolaan sumber daya yang dipercayakan kepadanya dan ketaatannya pada peraturan perundang-undangan. Dalam Peraturan Pemerintah Nomor 58 tentang Pengelolaan Keuangan Daerah, dinyatakan bahwa keuangan daerah harus dikelola secara tertib, taat pada peraturan perundang-undangan, efisien, ekonomis, efektif, transparan, dan bertanggung jawab dengan memperhatikan asas keadilan, kepatuhan, dan manfaat untuk masyarakat.

Transparansi adalah keterbukaan atas semua tindakan dan kebijakan yang diambil oleh pemerintah (Hamid Muhammad 2007:31). Prinsip transparansi menciptakan kepercayaan timbal-balik antara pemerintah dan masyarakat melalui penyediaan informasi dan menjamin kemudahan di dalam memperoleh informasi yang akurat dan memadai. Menurut Logos $(2003$; 24) transparansi dan akuntabilitas merupakan konsep yang berkaitan erat satu dengan yang lain, karena tanpa transparansi tidak mungkin ada akuntabilitas. Sebaliknya transparansi tidak akan banyak bermanfaat tanpa dilengkapi dengan akuntabilitas. Seperti halnya di bidang kebijakan publik yang lain, keberadaan transparansi dan akuntabilitas merupakan syarat mutlak untuk membangun kebijakan dan institusi yang efektif, efisien, dan adil (equitable). Lingkup transparansi dan akuntabilitas harus menjangkau beberapa tingkat kebijakan mulai dari perumusan kebijakan, pengambilan keputusan, sampai pada pelaksanaannya yang terjadi di segenap institusi.

Transparansi pada akhirnya akan menciptakan horizontal accountability antara pemerintah daerah dengan masyarakat sehingga tercipta pemerintahan daerah yang bersih, efektif, efisien, akuntabel dan responsive terhadap aspirasi dan kepentingan masyarakat. Transparansi adalah prinsip yang menjamain akses atau kebebasan bagi setiap orang untuk memperoleh informasi tentang penyelenggaraan pemerintahan, yakni 
informasi tentang kebijakan proses pembuatan dan pelaksanaanya serta hasil-hasil yang dicapai. Transparansi adalah adanya kebijakan terbuka bagi pengawasan. Sedangkan yang dimaksud dengan infoermasi adalah informasi mengenai setiap aspek kebijakan pemerintah yang dapat dijangkau publik. Keterbukaan informasi diharapkan akan menghasilkan persaingan politik yang sehat, toleran, dan kebijakan dibuat beradsarkan preferensi publik. Makna dari transparansi dalam penyelenggaraan pemerintahan daerah dapat dilihat dalam dua hal yaitu; (1) salah satu wujud pertanggung jawaban pemerintah kepada rakyat, dan (2) upaya peningkatan manajemen pengelolaan dan penyelenggaraan pemerintahan yang baik dan mengurangi kesempatan praktek kolusi, korupsi dan nepotisme $(\mathrm{KKN})$.

Sedangkan transparansi penyelenggaraan pemerintahan daerah dalam hubungannya dengan pemerintah daerah perlu kiranya perhatian terhadap beberapa hal berikut; (1) publikasi dan sosialisasi kebijakan-kebijakan pemerintah daerah dalam penyelenggaraan pemerintahan daerah, (2) publikasi dan sosialisasi regulasi yang dikeluarkan pemerintah daerah tentang berbagai perizinan dan prosedurnya, (3) publikasi dan sosialisasi tentang prosedur dan tata kerja dari pemerintah daerah, (4) transparansi dalam penawaran dan penetapan tender atau kontrak proyek-proyek pemerintah daerah kepada pihak ketiga, dan (5) kesempatan masyarakat untuk mengakses informasi yang jujur, benar dan tidak diskriminatif dari pemerintah daerah dalam penyelenggaraan pemerintahan daerah.

Sehingga dengan adanya transparansi pengelolaan keuangan pemerintah daerah, maka pemerintah daerah akan mendapat kepercayaan dan dukungan dari publik, dan pemerintah tentunya akan bekerja lebih serius dan disiplin, proses perencanaan dan pelaksanaan anggaran pemerintah lebih partisipatif dan pro poor, mekanisme pengawasan baik internal maupun eksternal akan semakin kuat sehingga terhindar dari praktik KKN (Douglas, 2006:31). Disamping itu, dengan meningkatkan transparansi keuangan maka diharapkan kualitas pelayanan publik akan semakin baik dan akan terwujud tata pemerintahan yang baik dan bersih (good governance dan clean government).

Transparansi dibangun atas dasar arus informasi yang bebas. Seluruh proses pemerintahan, lembaga-lembaga, dan informasi perlu dapat diakses oleh pihak -pihak yang berkepentingan dan informasi yang tersedia harus memadai agar dapat dimengerti dan dipantau. Ada beberapa pengertia tentang transparansi publik yaitu: 
Andrianto (2007:20) Transparansi adalah Keterbukaan secara sungguh-sungguh, menyeluruh, dan memberi tempat bagi partisipasi aktif dari seluruh lapisan masyarakat dalam proses pengelolaan sumber daya publik. Selain itu, juga dirmuskan oleh Tanjung (Andrianto, 2007:35) menyatakan Transparansi adalah Keterbukaan dan kejujuran kepada masyarakat berdasarkan pertimbangan bahwa masyarakat memiliki hak mengetahui secara terbuka dan menyeluruh atas pertanggung jawaban pemerintahan dalam sumber daya yang di percayakan kepadanya dan ketaatannya pada peraturan perundang-undangan.

Adapun Indikator transparansi yaitu prinsip yang menjamin akses atau kebebasan bagi setiap orang untuk memperoleh informasi tentang penyelenggaraan pemerintahan, yakni informasi mengenai kebijakan, proses pembuatan, pelaksanaan, dan hasil yang dicapai. Menurut Mardiasmo (2004:17) bahwa prinsip ini menekankan beberapa aspek yaitu:

1. Komunikasi publik oleh pemerintah.

2. Hak masyarakat terhadap akses informasi.

3. Penyediaan informasi yang jelas tentang tanggung jawab.

4. Kemudahan akses informasi.

5. Menyusun suatu mekanisme pengaduan jika ada peraturan yang dilanggar atau permintaan untuk membayar uang suap.

6. Meningkatkan arus informasi melalui kerjasama dengan media massa dan lembaga non pemerintah.

Menurut Krisna (2003 : 15) bentuk transparansi yaitu:

1. Penyediaan informasi yang jelas tentang prosedur, biaya, dan tanggung jawab. Pemerintah harus terbuka mungkin menganai keputusan dan tindakan yang mereka ambil. Mereka harus mempunyai alasan untuk setiap keputusan dan informasi rahasia jika masayarakat dan staff menginginkannya. Cara untuk mengetahui penyediaan informasi yang jelas tentang prosedur, biaya dan tanggung jawab yaitu dengan adanya situs internet yang menyediakan informasi tentang laporan pengelolaaan keuangan daerah.

2. Kemudahan akses informasi.

Akses pada informasi dan akurat dan tepat waktu tentang kebijakan pendidikan pemerintahan yang sangat penting bagi pengambilan keputusan oleh para sekolah yang ada dan cara untuk mengetahui kemudahan akses informasi yaitu adanya acuan 
pelayanan, adanya perawatan data, adanya laporan kegiatan publik dan prosedur keluhan.

3. Menyusun suatu mekanisme pengaduan.

Cara untuk mengetahui menyusun suatu mekanisme pengaduan yaitu adanya kotak saran untuk membantu system pengelolaan keuangan daerah, adanya respon dari Bawasda terhadap pengaduan pelanggaran peraturan atau permintaan pembayaran uang suap dalam pengelolaan keuangan daerah.

4. Meningkatkan arus informasi.

Cara meningkatkan arus informasi yaitu melalui kerjasama dengan media massa. Cara untuk mengetahui meningkatkan arus informasi yaitu adanya informasi yang menampung pernyataan-pernyataan masyarakat atau staff tentang pengelolaan keuangan daerah di dinas pendidikan.

Transparansi pengelolaan keuangan daerah merupakan salah satu bentuk efektivitas dan efisiensi penyelenggaraan tata kelola pemerintahan yang baik (good governance government). Menurut Andrianto, (2007:21) transparansi dan akuntabilitas pengelolaan keuangan ini memiliki ciri dengan indikator:

1. Tersedianya informasi yang memadai pada setiap proses penyusunan dan implementasi kebijakan publik;

2. Adanya akses pada informasi yang siap, mudah dijangkau, bebas diperoleh, dan tepat waktu;

3. Adanya kesesuaian antara pelaksanaan dengan standar prosedur pelaksanaan; dan

4. Adanya sanksi yang ditetapkan atas kesalahan atau kelalaian dalam pelaksanaan kegiatan

\section{KESIMPULAN}

Kenyataan yang terjadi menunjukkan bahwa dalam pengelolaan anggaran/keuangan daerah seolah-olah masih disusun dengan konsep yang kurang matang/sempurna, dalam waktu yang terburu-buru dan akhirnya lahir secara prematur atau tidak baik. Regulasi yang lahir prematur tentu mengandung berbagai kelemahan dan kekurangan bahkan ketidakjelasan arahnya. Apalagi kalau dilahirkan dalam kondisi suhu politik yang tinggi yaitu adanya perang kepentingan antar instansi yang merasa berwenang untuk mengaturnya.

Dalam hal ini, terkesan tidak ada koordinasi khususnya di tingkat pemerintah daerah dalam membuat dan menetapkan peraturan pelaksanaan pada tingkat operasional yang lebih 
rendah terhadap pengelolaan keuangan dan transparansi tersebut. Pada akhirnya daerah harus mengeluarkan dana kas daerah yang tidak sedikit demi implementasi peraturan yang di buatnya tersebut. Tingkat transparansi pengelolaan keuangan khususnya di tingkat daerah masih banyak mengandung ketidakjelasan dan ketidaktegasan dalam memberikan pedoman kepada arah kebijakan pengelolaan keuangan daerah. Hal ini mengakibatkan kebingungan pemerintah daerah dalam pengelolaan keuangannya.

Kita tentu saja tidak menginginkan semangat otonomi daerah ini menjadi ajang memanfaatkan ketidaktahuan sumber daya manusia di daerah, menjadikan daerah sebagai 'sapi perahan' dan 'kelinci percobaan' saja. Kita menginginkan regulasi yang dapat memberikan kepastian dan kejelasan pemerintah daerah dalam tata kelola atau manajemen keuangan daerah dan tingkat transparansi keuangan daerah itu sendiri.

Tulisan ini lebih dimaksudkan sebagai kritik seorang warganegara yang ingin melihat pemerintahan ini dikelola secara professional dan mengutamakan kepentingan negara di atas kepentingan individu/golongan.

\section{DAFTAR PUSTAKA}

Mardiasmo. (2006). Perwujudan Transparansi dan Akuntabilitas Publik Melalui Akuntansi Sektor Publik: Suatu Saran Good Governance. Jurnal Akuntansi Pemerintahan. Volume 2 Nomor 1. Mei 2006. Hal 2-4

Mardiasmo. (2004). Otonomi \& Manajemen Keuangan Daerah, Penerbit ANDI, Yogyakarta Sugijanto.2002. Peranan Sistem Akuntansi Pemerintah Pusat Dalam Meningkatkan Akuntabilitas Keuangan dan Implikasi UU No. 22/25 Tahun 1999. Lintasan Ekonomi.Volume XIX Nomor 1.Hal. 50-66

Suwardjono. 2005. Teori Akuntansi: Perekayasaan Pelaporan Keuangan. Edisi Ketiga. Yogyakarta: BPFE.

Yani, Ahmad. 2002. Hubungan Keuangan Antara Pemerintahan Pusat dan Daerah di Indonesia. Jakarta. Rajawali Pers

Koesoemahatmadja, Pengantar ke Arah Sistem Pemerintahan Daerah di Indonesia, Bina Cipta Karya, Bandung, 1979

Lembaga Administrasi Negara dan Badan Pengawasan Keuangan dan Pembangunan, Akuntabilitas Dan Good Goverenance” Lembaga Admnistrasi Negara dan Badan Penagwas Keuangan dan Pembangunan, Jakarta, 2000

Literatur Pendukung: 
Undang-Undang No. 22 Tahun 1999 tentang Pemerintahan Daerah,

Undang-Undang No. 25 Tahun 1999 tentang Perimbangan Keuangan antara Pemerintah Pusat dan Daerah,

Undang-undang Nomor 17 Tahun 2003 tentang Keuangan Negara,

Undang-Undang Nomor 1 Tahun 2004 tentang Perbendaharaan Negara,

Undang-Undang Nomor 32 Tahun 2004 tentang Pemerintahan Daerah,

Undang-undang Nomor 23 Tahun 2014 tentang Pemerintah Daerah

Undang-Undang Nomor 33 Tahun 2004 tentang Perimbangan Keuangan antara Pemerintah Pusat dan Pemerintah Daerah,

Peraturan Pemerintah Nomor 24Tahun 2005 tentang Standar Akuntansi Pemerintahan

Peraturan Pemerintah Nomor 58 Tahun 2005 tentang Pengelolaan Keuangan Daerah.

Peraturan Menteri Dalam Negeri No. 59, Tahun 2007 tentang Pengelolaan Keuangan Daerah.

Peraturan Pemerintah Nomor 58 Tahun 2005 tentang Pengelolaan Keuangan Daerah

Peraturan Menteri Dalam Negeri (Permendagri) Nomor 13 tahun 2006 tentang Pedoman Pengelolaan Keuangan Daerah. 